\title{
Article
}

\section{Learner-Centered Inquiry in Undergraduate Biology: Positive Relationships with Long-Term Student Achievement}

\author{
Terry L. Derting* and Diane Ebert-May ${ }^{\dagger}$
}

*Department of Biological Sciences, Murray State University, Murray, KY 42071; and 'Department of Plant Biology, Michigan State University, East Lansing, MI 48824

Submitted February 16, 2010; Revised May 18, 2010; Accepted May 24, 2010

Monitoring Editor: Diane O'Dowd

\begin{abstract}
We determined short- and long-term correlates of a revised introductory biology curriculum on understanding of biology as a process of inquiry and learning of content. In the original curriculum students completed two traditional lecture-based introductory courses. In the revised curriculum students completed two new learner-centered, inquiry-based courses. The new courses differed significantly from those of the original curriculum through emphases on critical thinking, collaborative work, and/or inquiry-based activities. Assessments were administered to compare student understanding of the process of biological science and content knowledge in the two curricula. More seniors who completed the revised curriculum had high-level profiles on the Views About Science Survey for Biology compared with seniors who completed the original curriculum. Also as seniors, students who completed the revised curriculum scored higher on the standardized Biology Field Test. Our results showed that an intense inquiry-based learnercentered learning experience early in the biology curriculum was associated with long-term improvements in learning. We propose that students learned to learn science in the new courses which, in turn, influenced their learning in subsequent courses. Studies that determine causal effects of learner-centered inquiry-based approaches, rather than correlative relationships, are needed to test our proposed explanation.
\end{abstract}

\section{INTRODUCTION}

Science faculty across the country are experimenting with active learner-centered instructional strategies that are grounded in research about how people learn (e.g., Bransford et al., 1999; Wood and Gentile, 2003; Donovan and Bransford, 2005; Ebert-May and Hodder, 2008). Recent reviews report that active learning is more effective than pas-

DOI: $10.1187 /$ cbe.10-02-0011

Address correspondence to: Terry L. Derting (terry.derting@ murraystate.edu).

(C) 2010 T. L. Derting and D. Ebert-May. CBE-Life Sciences Education (C) 2010 The American Society for Cell Biology. This article is distributed by The American Society for Cell Biology under license from the author(s). It is available to the public under an AttributionNoncommercial-Share Alike 3.0 Unported Creative Commons License (http://creativecommons.org/licenses/by-nc-sa/3.0). sive learning in undergraduate engineering and science education (Prince, 2004; Michael, 2006). Some of the major characteristics of learner-centered strategies include students going beyond listening and taking notes, toward working on activities in collaborative groups, and developing higher-order cognitive skills (i.e., application, analysis, synthesis; Bloom, 1956). Likewise, numerous studies have documented that "scientific teaching" in undergraduate science courses increases the level of student learning within an individual course (Handelsman et al., 2004; DeHaan, 2005; Freeman et al., 2007). Scientific teaching brings the thinking, creativity, rigor, and experimentation that defines research to all students through tested instructional methods that are effective for diverse populations of students (Phillips et al., 2008).

Despite the profusion of studies documenting increased learning through active engagement of students (Udovic et al., 2002; Knight and Wood, 2005; Michael, 2006; Freeman et 
al., 2007), traditional teacher-centered pedagogy continues to dominate our undergraduate science classrooms. Published reports on the impact of reforming undergraduate education in the sciences are not sufficient to promote widespread change in faculty teaching practices (Seymour, 2006; Henderson and Dancy, 2007). What then is lacking in arguments for change? Barriers to change in teaching are complex, but a contributing factor may be the evidence for change itself. Most reports of the impacts of reformed teaching are shortterm in nature, focusing on outcomes associated with a single course or semester of study (e.g., DeHaan, 2005; Handelsman et al., 2004). A more compelling case for teaching reform at the departmental or college level may emerge by documenting long-term impacts of learner-centered strategies on student performance in an entire bachelor's degree program. In addition, documentation of effects of reformed teaching on "high-stakes" national assessment scores, such as scores on the Medical College Assessment Test (MCAT) and the Graduate Record Examination (GRE), may further stimulate science departments to make changes that facilitate implementation of student-centered approaches to learning.

Our research focused on long-term correlates of reformed teaching. Specifically, we investigated the question "Is the infusion of two new introductory courses early in a student's curriculum, both based on learner-centered inquirybased principles, associated with improved long-term understanding of biological concepts and biology as a process of inquiry?" To determine the extent to which a short-term intervention was correlated with long-term student performance, we studied a revised biology curriculum implemented at the beginning of the biology major, and assessed potential correlates at the end of the major. The curriculum revisions were focused on learner-centered instruction as an alternative approach to traditional instruction because learner-centered teaching increases students' knowledge and can improve attitudes toward learning (e.g., Ebert-May et al., 2003; Knight and Wood, 2005). We used introductory courses because those are core courses that all students complete in the major. In addition, introductory courses are the target of many reform efforts nationally (National Research Council [NRC], 2003; Handelsman et al., 2004), yet there is an absence of data on long-term impacts.

\section{MATERIALS AND METHODS}

\section{Revised and Original Curricula}

Our investigation had a quasi-experimental comparative design, because of the authentic educational context in which the research was performed. Our study subjects were undergraduate biology majors enrolled at a comprehensive public institution (i.e., Murray State University [MSU]), between 2000 and 2005. In the original curriculum, which was available until 2003, students enrolled in Zoology (BIO 121) and Botany (BIO 122) during their first two semesters. Class sizes ranged from 31 to 63 students, with an average of 53 students. In the revised curriculum, which was available beginning in 2001 after one pilot section was taught in 2000, two new introductory courses were developed (Biological Inquiry and Analysis [BIA]; The Cellular Basis of Life [TCBL]; Table 1). These two courses became required core
Table 1. Sequence of core courses in the original and revised biology major

\begin{tabular}{|c|c|c|}
\hline & $\begin{array}{l}\text { Original curriculum } \\
\text { (available until 2003) }\end{array}$ & $\begin{array}{l}\text { Revised curriculum } \\
\text { (available in 2000, } \\
\text { required in } \\
\text { 2003-present) }\end{array}$ \\
\hline Semester 1 & $\begin{array}{c}\text { *Zoology (BIO 121) or } \\
{ }^{*} \text { Botany (BIO 122) }\end{array}$ & $\begin{array}{l}\text { *BIA (Bio 116) } \\
{ }^{*} \text { TCBL (BIO 115) }\end{array}$ \\
\hline Semester 2 & $\begin{array}{l}\text { Zoology (BIO 121) or } \\
\text { Botany (BIO 122) }\end{array}$ & $\begin{array}{c}\text { *Zoology (BIO 221) or } \\
\text { *Botany (BIO 222) }\end{array}$ \\
\hline Semester 3 & $\begin{array}{l}\text { Begin upper-level core } \\
\text { courses (300-level): } \\
{ }^{*} \text { Ecology (BIO 330) } \\
{ }^{*} \text { Genetics (BIO 333) } \\
{ }^{*} \text { Microbiology (BIO 300) or } \\
\text { Cell Biology (BIO 321) }\end{array}$ & $\begin{array}{l}\text { Zoology (BIO 221) or } \\
\text { Botany (BIO 222) }\end{array}$ \\
\hline $\begin{array}{l}\text { Semester } \\
\quad 4-8\end{array}$ & $\begin{array}{l}\text { Continue upper-level core } \\
\text { \& elective courses } \\
(\geq 300 \text {-level })\end{array}$ & $\begin{array}{l}\text { Upper-level core \& } \\
\text { elective courses } \\
(\geq 300 \text {-level): } \\
{ }^{*} \text { Genetics (BIO 333) }\end{array}$ \\
\hline
\end{tabular}

An asterisk $(*)$ indicates a required core course.

courses for all incoming majors in Fall 2003. The BIA course met in small sections of 32 students, who were taught by six different faculty over the course of the project. The sections were taught in a classroom with tables that seated four students each. The TCBL course was in a large lecture hall with an average class size of 177 students. One professor taught TCBL throughout the study. Faculty who taught the new courses were largely early-career educators who had been teaching at MSU from one to seven years at the outset of the project. Only two of the seven faculty had significant prior training in the use of learner-centered, active learning approaches to teaching.

Two additional changes were made in core requirements in the revised curriculum. First, students were no longer required to take Cell Biology/Microbiology and Ecology as core upper-level courses. Second, the original introductory courses (i.e., Zoology and Botany) were moved from the 100to the 200-level and renumbered as BIO 221 and 222, respectively. Three different faculty (six faculty total) taught Zoology and Botany during the years of our study, using a traditional lecture approach. We defined "traditional" as teachers providing information with little student-teacher or student-student interaction during a lecture period. Some faculty incorporated an inquiry-based activity that involved group work in the laboratory portion of the course, but all retained a systematic approach to identify and compare plant and animal specimens in the majority of the laboratory sessions. Likewise, some faculty reduced the time they devoted to teaching cell-related topics due to the new TCBL course. Most faculty, however, continued to use the same course syllabi and maintained the same basic course content (personal communication).

\section{Characteristics of the New Courses}

Both new courses incorporated learner-centered inquirybased practices (Smith et al., 2005). The new TCBL course 
(BIO 115) focused on cell and molecular biology by actively engaging students in scientific questions and discussing research that led to major discoveries in cell biology. For each broad concept, students practiced building an extended working vocabulary of scientific terms to use in subsequent biology courses. During class, students discussed problems designed to promote critical analysis. Formative assessments that probed and revealed students' thinking and understanding of terms were gathered using a Personal Response System (PRS; i.e., clickers). Descriptions of sample class sessions are provided in Supplemental Material A.

The other new course, BIA (BIO 116), focused on 1) student understanding and practice of science as a process of inquiry that is evidence-based, and 2) the theory of evolution. Students conducted two types of activities each week. The first type was student research. Students completed three inquiry-based research modules; the first on animal behavior, the second on ecology, and the third on a project related to any area of biology. In each module students posed their own research questions and hypotheses, presented and critiqued student research proposals and final research papers, collected and statistically analyzed their data, and presented their research in the form of a scientific journal article or poster. In the second type of activity, evolution was used as a theme to further engage students in the process of science. Students participated in discussions about the nature of science and worked with open-ended simulations about evolution in which they asked research questions, tested hypotheses, and inquired into new problems. Methods and activities used in BIA are described in further detail in Supplemental Material B. On completion of the two new courses, students then enrolled in Zoology (BIO 221) and Botany (BIO 222) within the next two semesters (Table 1).

To ascertain that the new courses were indeed more learner-centered compared with the introductory biology courses in the original curriculum (i.e., BIO 121 and 122), we used the Science Course Questionnaire (adapted from Partnerships for Reform Initiatives in Science and Mathematics T4 Undergraduate Initiative, Eisenhower Foundation 1999; Supplemental Material C). The questionnaire was completed by students in TCBL and BIA in Fall 2001, and students in the original Zoology (BIO 121) and Botany (BIO 122) courses during Spring 2001. Many of the students who completed the questionnaire in the fall courses constituted the pool of students who completed the survey during the spring courses. Students in the 200-level Zoology (BIO 221) and Botany (BIO 222) completed the questionnaire during Spring 2002. The results provided information on student perceptions of the activities and pedagogical approaches used in the new inquiry-based and renumbered courses and the original introductory courses.

\section{Assessment Populations}

Because the revised curriculum was implemented incrementally, we were able to compare learning by students from both the revised and original curriculum as they moved through the major. For all analyses, students from the revised curriculum were defined as those who completed both of the two new courses. It was not possible to evaluate the impacts of each new course individually because most stu- dents took the two courses simultaneously. Students from the original curriculum were defined as those who did not complete either new course before taking the assessments or graduating. These were students who enrolled before complete replacement of the original curriculum by the revised one in 2003, students who received substitute credit for the new courses by scoring a 5 on the Advanced Placement (AP) Biology Exam in high school, and transfer students who had already completed a one-year introductory biology course sequence before transferring from another institution. Neither of these two groups (i.e., revised and original curriculum majors) comprised a single student cohort and individual students were not tracked over time. Student cohorts were not a stable unit. A cohort's composition changes during the four years of the biology major, with some students switching to other majors and other students moving into the biology major. Tracking of students was not possible as anonymity of students was required throughout the project. Thus, at any point in time when assessment data were collected, students were assigned to the new or original curriculum group depending on their completion of the two new courses.

To evaluate potential similarities and differences between the two student populations, we collected demographic and academic performance data from the students. All assessment procedures were approved by the Institutional Review Board for Research with Human Subjects. Students participated in each assessment on a voluntary basis; thus, not all data (e.g., senior grade point average [GPA], American College Testing [ACT] score, survey results, demographic data) were available for all students. Also, to reduce excessive taking of assessments by students as they moved through the major, some assessments were only administered during one or two academic years.

\section{Assessments}

Two assessments were used to evaluate potential impacts of the new courses during a five-year period: 1) student understanding of biology as a process of inquiry (Views About Science Survey for Biology; Halloun, 1996) and 2) knowledge of biological concepts at the end of the major (Major Field Test in Biology 2000-2005 version, Educational Testing Service [ETS], Princeton, NJ). Seniors typically took the assessments midway through the Senior Seminar course (BIO 499), a required capstone course in the biology major. Seniors usually enrolled in Senior Seminar the semester before graduating. There were no tangible incentives (e.g., grade points) for students to do their best on the assessments; however, they were told of the importance of their responses to improving educational practices in biology at MSU and their potential use of their Biology Field Test scores when seeking employment or admission to graduate or professional school.

\section{Views About Biology Survey (VABS)}

The VABS was developed and validated as an assessment tool that probes student beliefs about the nature and learning of science (Halloun and Hestenes, 1996). First- and second-year students in the two new courses completed the VABS during Fall 2002 and Fall 2003. Graduating seniors completed the VABS at the end of each semester during 
Spring 2004 through Fall 2005. Based on responses to survey questions, students were placed in one of four profiles: folk, low transitional, high transitional, or expert, with an expert profile resembling that of a professional scientist. To determine whether student profiles from the VABS were indicative of student learning, we compared mean student grades among the four profiles for several biology courses and student scores on the Biology Field Test.

\section{Major Field Test in Biology (BFT)}

The BFT was a required test taken by all biology majors during their senior year. The BFT scores were for assessment purposes only and did not affect a student's GPA. Only students who completed the BFT before 2005 were eligible for inclusion in the analysis because ETS made significant revisions to the BFT in 2005. As a result of these revisions, ETS states that scores from students taking the test after 2005 cannot be compared with those of students taking the test in earlier years.

To determine the types of cognitive skills measured by the BFT, we analyzed a sample of test items and conducted interviews with senior students. The BFT consists of multiple-choice questions. We (T.L.D. and D.E.-M.) independently used Bloom's Taxonomy of Educational Objectives: The Cognitive Domain (1956) to classify the cognitive skill level targeted by each question in one BFT test booklet. The agreement between our individual classification results was greater than $90 \%$. Our results showed that the test questions assessed a range of cognitive thinking skills. The majority of test points came from lower-level cognition (convergent) questions (i.e., knowledge and comprehension). Approximately $25 \%$ of the test points involved higher-level cognition (i.e., divergent thinking) questions (application and analysis; Bloom 1956).

To further verify the alignment between student scores on the BFT and student cognitive abilities, interviews were conducted by the senior author, nine biology faculty, two postdoctoral researchers, and one professional wildlife biologist. Except for the author, none of the interviewers were associated with the curriculum reform project. Most faculty conducted six interviews, using the protocol in Supplemental Material D. In the 2004 academic year, 31 graduating seniors were offered a small stipend for voluntary participation in the interviews. Only two of the 31 students had completed the new curriculum. The faculty interviewers independently developed a pool of questions (see Supplemental Material E) about key concepts that they deemed important in biology. The questions specifically addressed all levels of cognitive thinking as described by Bloom's taxonomy. All questions within a specific section of the question pool were considered to be equivalent in terms of the types of thinking skills required. At the end of each half-hour interview, the interviewer scored the student's responses for two types of questions: convergent (i.e., knowledge, comprehension, and application) and divergent (analysis, synthesis, and evaluation) using a rating form and scoring rubrics (see Supplemental Material F).

Each student participant was interviewed one-on-one by three different interviewers, each of whom asked questions of their own choosing from the question pool. Thus, the questions asked of students differed depending on their specific interviewers. We used a large pool of potential questions rather than a narrow set of fixed questions to allow faculty to fully probe student knowledge and higher-level cognitive skills. An initial assessment of students' lower-level cognitive skills was easily made after asking lower-level questions that focused on several different subdisciplines within biology. Assessment of higher-level thinking skills required more time and probing. Our objective was not to determine whether students could use higher-level thinking across a number of specific areas of study. Rather, we aimed to determine the extent to which students could use higher-level thinking skills when asked questions with which they appeared to have some level of expertise; such as those closely related to their area of study (e.g., wildlife biology, pre-medicine). Thus, all students presumably had an equal opportunity to demonstrate their best cognitive skills.

\section{Data Analysis}

Data were first examined to confirm their suitability (normality and homogeneity of variances) for use with parametric statistical analyses. Significant differences between group means of measured variables were determined using general linear model analyses of variance (ANOVA) and $t$ tests. Equality of variances of subject groups was tested before performing $t$ tests. Differences in frequency distributions of measured variables among groups were determined using chi-square $\left(\chi^{2}\right)$ analyses. It was not possible to compare individual student responses over time using paired statistical analyses because identifying information about students was not maintained in the database per Institutional Review Board guidelines. To determine the contribution of measured variables to explaining variation in student performance on the BFT, a multivariate stepwise regression analysis was used. Analyses were conducted using SAS Version 9.2 (SAS Institute, 2008). For all statistical tests, differences were considered statistically significant at $p \leq$ 0.05 . Data are presented as arithmetic means $\pm 1 \mathrm{SE}$.

\section{RESULTS}

\section{Student Populations}

We characterized the study populations and tested for differences between them. Demographic and academic history data were compiled from samples of first-year and senior biology majors in the original and revised curriculum. We found no significant differences in any demographic category between students who completed the revised curriculum and those in the original curriculum in either the firstyear or the senior sample (Table 2; all $\chi^{2}$ tests, $p>0.05$ ). Likewise, there were no statistically significant differences in composite ACT scores (all $t$ tests, $p>0.05$ ) or the total number of biology credit hours completed (all $t$ tests, $p>$ 0.05 ) between students in the original compared with the revised curriculum.

\section{Science Course Questionnaire (SCQ)}

Based on responses from the SCQ, student perceptions of BIA and, to a lesser extent, TCBL differed from those of students who completed the traditional introductory courses (BIO 121 and 122; Tables 3 and 4). For example, in 
Table 2. Demographic and academic history data for the study populations (i.e., first-year and senior students) in the original and revised curriculum

\begin{tabular}{|c|c|c|c|c|c|}
\hline Study group & $\begin{array}{c}\text { Gender } \\
(\% \text { male: } \% \text { female })\end{array}$ & $\begin{array}{c}\text { Parents' highest } \\
\text { level of } \\
\text { education }\end{array}$ & $\begin{array}{l}\text { Hours } \\
\text { employed }\end{array}$ & $\begin{array}{l}\text { Composite ACT } \\
\text { score }(\bar{X} \pm 1 \mathrm{SE})\end{array}$ & $\begin{array}{l}\text { Biology credit } \\
\text { hours completed } \\
(\bar{X} \pm 1 \text { SE })\end{array}$ \\
\hline \multicolumn{6}{|l|}{ First-year students } \\
\hline Original curriculum $(\mathrm{n}=136)$ & $35: 65$ & $\begin{array}{l}\text { Both HS: } 32 \% \\
\geq 1 \text { BA/BS: } 40 \% \\
\geq 1 \text { Grad.: } 27 \%\end{array}$ & $\begin{array}{r}0: 48 \% \\
1-8: 6 \% \\
9-16: 21 \% \\
\geq 17: 25 \%\end{array}$ & $23.2 \pm 0.5$ & \\
\hline Revised curriculum (n = 112) & $38: 62$ & $\begin{array}{l}\text { Both HS: } 35 \% \\
\geq 1 \text { BA/BS: } 28 \% \\
\geq 1 \text { Grad.: } 38 \%\end{array}$ & $\begin{array}{r}0: 44 \% \\
1-8: 11 \% \\
9-16: 18 \% \\
\geq 17: 27 \%\end{array}$ & $23.3 \pm 0.6$ & \\
\hline \multicolumn{6}{|l|}{ Senior students } \\
\hline Original curriculum $(\mathrm{n}=79)$ & $46: 53$ & $\begin{array}{l}\text { Both HS: } 38 \% \\
\geq 1 \text { BA/BS: } 38 \% \\
\geq 1 \text { Grad.: } 23 \%\end{array}$ & $\begin{array}{r}0: 25 \% \\
1-8: 17 \% \\
9-16: 19 \% \\
\geq 17: 39 \%\end{array}$ & $24.2 \pm 0.4$ & $43.7 \pm 1.2$ \\
\hline Revised curriculum $(\mathrm{n}=84)$ & $52: 48$ & $\begin{array}{l}\text { Both HS: } 37 \% \\
\geq 1 \text { BA/BS: } 37 \% \\
\geq 1 \text { Grad.: } 22 \%\end{array}$ & $\begin{array}{r}0: 37 \% \\
1-8: 10 \% \\
9-16: 21 \% \\
\geq 17: 32 \%\end{array}$ & $24.7 \pm 0.3$ & $46.0 \pm 1.3$ \\
\hline
\end{tabular}

HS, high-school degree; BA/BS, bachelor's degree; Grad, graduate degree; ACT, American College Testing.

both new courses students indicated that they were often engaged in collaborative work. Likewise, both of the new courses were described by students as focusing on both how scientists think and work and learning important science concepts (Tables 3 and 4). BIA was described as a course containing numerous activities that were geared toward best practices in inquiry-based teaching and learning. Students in BIA reported that they stayed on a topic until most students understood it, knowledge was learned more from in-class activities than a text, inquiry-based activities extended for more than one class session, and making logical conclusions from data was more important than getting an expected result. Students also indicated that grading in BIA was based on understanding, justifying, and applying information rather than only knowledge of terms and facts (Table 3). Lastly, students reported that their performance depended significantly more on their ability to analyze information and reach logical conclusions, connect and apply ideas, and communicate clearly in writing and orally compared with the responses of students in the traditional courses (Tables 3 and 4).

We also used the results of the SCQ to assess similarities and differences between the original 100-level Zoology and Botany courses and their 200-level counterparts in the revised curriculum. Many aspects of the 200-level courses did not differ from the original 100-level courses. Students did report, however, a greater emphasis on learning how scientists think and work, and on grading that assessed students' ability to analyze data, justify conclusions, and apply information in the 200-level compared with the original 100-level courses (Table 3). This difference stemmed from the inclusion of an inquiry-based laboratory in the 200-level courses. For classroom activities there were many differences in student perceptions of the 100- and 200-level courses. Most of these differences indicated significantly less student-student and student-professor interaction, less evaluation of the validity of arguments, and more simple memorization of information without conceptual understanding in the 200level courses (Table 4).

\section{Views about Biology Survey}

Student profiles on the VABS were a useful indicator of student understanding of biology as a process of inquiry as well as student learning. Learning by biology majors was generally aligned with their VABS profile at the end of a course (Figure 1, A-D) and at the end of the major (Figure 1E). From the 100- through 300-level, students with a folk profile consistently had the lowest final course grades on average, while those with an expert profile had the highest mean final grades. We also examined the relationship between final course grades and student profiles at the beginning, rather than the end, of BIA. Patterns like those in Figure 1 resulted, although the differences among means were smaller. The same results also occurred for total percentile scores on the BFT. The data shown in Figure 1E were from 71 seniors who completed the new courses and 58 who did not. The results were similar between the two groups with experts having total scores on the BFT that averaged at least twice as high as those of students with a folk or low transitional profile.

Completion of the revised curriculum was associated with long- but not short-term change in students' VABS profiles. The VABS was administered to first- and second-year students in Zoology (BIO 221) during the first two years in which the new curriculum (Table 1) was implemented (i.e., 2002 and 2003). Based on the first- and second-year student responses, there was no significant difference in the frequency distribution of profiles for students who had ( $\mathrm{n}=$ 
Table 3. Student ratings ( $\bar{X} \pm 1 \mathrm{SE}$ ) of paired statements (SCQ) that describe some aspects of the two traditional courses of the original introductory curriculum (100-level Zoology and Botany), the two new first-semester courses (TCBL and BIA), and the renumbered (200-level) Zoology and Botany courses

\begin{tabular}{|c|c|c|c|c|c|}
\hline Statement A & $\begin{array}{l}\text { Student responses } \\
\text { in the original } \\
\text { 100-level Zoology } \\
\text { and Botany } \\
(\mathrm{n}=98)\end{array}$ & $\begin{array}{l}\text { Student responses } \\
\text { in TCBL }(\mathrm{n}=78)\end{array}$ & $\begin{array}{l}\text { Students responses } \\
\text { in BIA }(\mathrm{n}=95)\end{array}$ & $\begin{array}{l}\text { Student responses } \\
\text { in 200-level } \\
\text { Zoology and } \\
\text { Botany }(\mathrm{n}=83)\end{array}$ & Statement B \\
\hline $\begin{array}{l}\text { Course focuses on learning } \\
\text { important science } \\
\text { concepts }\end{array}$ & $1.88 \pm 0.09^{\mathrm{A}}$ & $2.91 \pm 0.12^{\mathrm{BC}}$ & $3.07 \pm 0.10^{\mathrm{C}}$ & $2.63 \pm 0.12^{\mathrm{B}}$ & $\begin{array}{l}\text { Course focuses on learning } \\
\text { how scientists think and } \\
\text { work }\end{array}$ \\
\hline $\begin{array}{l}\text { Time for discussion of a } \\
\text { topic is limited by the } \\
\text { schedule on the syllabus }\end{array}$ & $2.91 \pm 0.13^{\mathrm{AB}}$ & $2.56 \pm 0.14^{\mathrm{A}}$ & $3.13 \pm 0.12^{\mathrm{B}}$ & $2.54 \pm 0.13^{\mathrm{A}}$ & $\begin{array}{l}\text { The class stays on a topic } \\
\text { until most students } \\
\text { understand it }\end{array}$ \\
\hline $\begin{array}{l}\text { Knowledge to be learned } \\
\text { is contained in the text } \\
\text { and illustrated by } \\
\text { in-class activities }\end{array}$ & $2.25 \pm 0.10^{\mathrm{A}}$ & $2.48 \pm 0.13^{\mathrm{A}}$ & $3.31 \pm 0.11^{\mathrm{B}}$ & $2.48 \pm 0.12^{\mathrm{A}}$ & $\begin{array}{l}\text { Knowledge to be learned } \\
\text { is generated by } \\
\text { discussing the results of } \\
\text { the in-class activities }\end{array}$ \\
\hline $\begin{array}{l}\text { Work in class is done } \\
\text { individually }\end{array}$ & $2.74 \pm 0.09^{\mathrm{A}}$ & $3.41 \pm 0.14^{\mathrm{B}}$ & $4.04 \pm 0.11^{\mathrm{C}}$ & $2.71 \pm 0.12^{\mathrm{A}}$ & $\begin{array}{l}\text { Work in class is done in } \\
\text { groups }\end{array}$ \\
\hline $\begin{array}{l}\text { Concepts are discussed in } \\
\text { class first, then } \\
\text { experienced through } \\
\text { inquiry-based activities }\end{array}$ & $2.61 \pm 0.08^{\mathrm{A}}$ & $2.84 \pm 0.15^{\mathrm{AB}}$ & $3.22 \pm 0.10^{\mathrm{B}}$ & $2.65 \pm 0.12^{\mathrm{A}}$ & $\begin{array}{l}\text { Concepts are experience } \\
\text { through inquiry-based } \\
\text { activities, then discussed } \\
\text { and elaborated on in } \\
\text { class }\end{array}$ \\
\hline $\begin{array}{l}\text { Hands-on investigations } \\
\text { are finished in one } \\
\text { period }\end{array}$ & $2.19 \pm 0.10^{\mathrm{A}}$ & NA & $3.77 \pm 0.11^{\mathrm{C}}$ & $3.16 \pm 0.14^{\mathrm{B}}$ & $\begin{array}{l}\text { Inquiry-based activities } \\
\text { extend over multiple } \\
\text { periods }\end{array}$ \\
\hline $\begin{array}{l}\text { When investigating } \\
\text { questions, the most } \\
\text { important goal is getting } \\
\text { the expected result }\end{array}$ & $3.42 \pm 0.08^{\mathrm{A}}$ & $3.48 \pm 0.14^{\mathrm{A}}$ & $3.93 \pm 0.11^{\mathrm{B}}$ & $3.15 \pm 0.12^{\mathrm{A}}$ & $\begin{array}{l}\text { When investigating } \\
\text { questions, the most } \\
\text { important goal is } \\
\text { making logical } \\
\text { conclusions from the } \\
\text { data }\end{array}$ \\
\hline $\begin{array}{l}\text { Grading is based mainly } \\
\text { on how well you know } \\
\text { terms and facts }\end{array}$ & $2.26 \pm 0.09^{\mathrm{A}}$ & $2.70 \pm 0.16^{\mathrm{B}}$ & $3.61 \pm 0.10^{\mathrm{C}}$ & $2.79 \pm 0.13^{\mathrm{B}}$ & $\begin{array}{l}\text { Grading is based mainly } \\
\text { on how well you } \\
\text { analyze data, justify } \\
\text { conclusions, and apply } \\
\text { information to new } \\
\text { situations }\end{array}$ \\
\hline
\end{tabular}

Means within a row which share a letter superscript (e.g., $\mathrm{A}$ and $\mathrm{AB}$ ) are not significantly different from each other (post hoc ANOVA, $p>$ 0.05). Possible responses were: $1=$ statement $\mathrm{A}$ much truer, $2=$ statement $\mathrm{A}$ somewhat truer, $3=$ both statements about the same, $4=$ statement B somewhat truer, and 5 = statement B much truer. NA indicates not applicable.

$85)$ or had not $(\mathrm{n}=69)$ completed the two new courses $\left(\chi^{2}=\right.$ 2.2 , d.f. $=3, p=0.54$ ). Regardless of whether students had or had not taken the new courses, more than half of each group (57 and 63\%, respectively) scored within the lower two profiles (i.e., folk and low transitional) at the end of a semester of Zoology.

Among seniors in their last semester of study in Spring 2004 through Fall 2005, however, the frequency distribution of student profiles differed significantly $\left(\chi^{2}=9.9\right.$, d.f. $=3$, $p=0.019)$. Fewer seniors $(16 \%)$ who had completed the two new courses had a folk profile compared with those who had not completed the new courses $\left(\chi^{2}=9.0\right.$, d.f. $=$ $1, p=0.003)$. With the reduction of students with a folk profile, there was a concurrent increase of $15 \%$ in the frequency of seniors with higher-level profiles (Figure 2). The difference in profile distributions of seniors was not attributable to a difference in the number of biology courses completed. There was no significant difference in the biology credit hours earned among the four profile groups of graduating seniors (ANOVA, d.f. = 3, 169; $\mathrm{F}=$ $0.455, p=0.71)$. Likewise, within each profile, seniors who had or had not completed the new courses had similar numbers of biology credit hours (all $t$ tests, $p>0.05$ ).

\section{Student Content Knowledge}

To evaluate short-term relationships between completion of the new courses and content knowledge, we examined final course and exam grades for first- and second-year students combined who were enrolled in Zoology (BIO 221) during 2002 and 2003. As with the VABS profile distributions, there were no significant differences in average final exam or final course grades between students who had or had not completed the two new courses ( $t$ test, 
Table 4. Student ratings $(\bar{X} \pm 1 \mathrm{SE}$ ) of the frequency of occurrence of various classroom activities (SCQ) for the two traditional courses of the original introductory curriculum (100-level Zoology and Botany), the two new first-semester courses (TCBL and BIA), and the renumbered (200-level) Zoology and Botany courses

\begin{tabular}{|c|c|c|c|c|}
\hline Survey statement & $\begin{array}{l}\text { Student responses in } \\
\text { the original 100-level } \\
\text { Zoology and Botany } \\
\qquad(n=98)\end{array}$ & $\begin{array}{l}\text { Student responses } \\
\text { in TCBL }(\mathrm{n}=78)\end{array}$ & $\begin{array}{l}\text { Student responses } \\
\text { in BIA }(\mathrm{n}=95)\end{array}$ & $\begin{array}{l}\text { Student responses in } \\
\text { 200-level Zoology } \\
\text { and Botany }(n=83)\end{array}$ \\
\hline
\end{tabular}

In this science class, how often do students:

Listen and take notes as the instructor talks to the class

Clarify concepts by responding to questions from the instructor

Explain concepts to other students

Work with groups of other students to

learn an idea or solve a problem

Make an oral presentation or

demonstration for the class

Evaluate the validity of an argument

Memorize information without applying it to an understanding of underlying concepts

Take tests with open-ended tasks (essay questions, performance tasks, etc.)

$\begin{array}{llll}4.80 \pm 0.06^{\mathrm{C}} & 4.56 \pm 0.09^{\mathrm{C}} & 3.16 \pm 0.11^{\mathrm{A}} & 3.89 \pm 0.13^{\mathrm{B}} \\ 4.04 \pm 0.10^{\mathrm{C}} & 4.10 \pm 0.14^{\mathrm{C}} & 3.53 \pm 0.11^{\mathrm{A}} & 2.99 \pm 0.14^{\mathrm{B}} \\ & & & \\ 3.57 \pm 0.12^{\mathrm{B}} & 3.01 \pm 0.14^{\mathrm{A}} & 3.59 \pm 0.10^{\mathrm{B}} & 2.56 \pm 0.13^{\mathrm{A}} \\ 3.47 \pm 0.09^{\mathrm{B}} & 4.49 \pm 0.11^{\mathrm{C}} & 4.60 \pm 0.07^{\mathrm{C}} & 3.11 \pm 0.13^{\mathrm{A}} \\ & & & \\ 1.63 \pm 0.12^{\mathrm{A}} & 1.33 \pm 0.10^{\mathrm{A}} & 3.27 \pm 0.07^{\mathrm{B}} & 1.38 \pm 0.13^{\mathrm{A}} \\ 3.33 \pm 0.12^{\mathrm{B}} & 3.28 \pm 0.13^{\mathrm{B}} & 2.70 \pm 0.11^{\mathrm{A}} & 2.45 \pm 0.12^{\mathrm{A}} \\ 2.00 \pm 0.11^{\mathrm{B}} & 1.58 \pm 0.10^{\mathrm{A}} & 2.53 \pm 0.11^{\mathrm{C}} & 2.92 \pm 0.12^{\mathrm{C}} \\ & & & \\ 2.00 \pm 0.11^{\mathrm{A}} & 1.58 \pm 0.10^{\mathrm{A}} & 2.54 \pm 0.11^{\mathrm{B}} & 2.26 \pm 0.12^{\mathrm{A}}\end{array}$

Means within a row which share a letter superscript (e.g., A and AB) are not significantly different from each other (post hoc ANOVA, $p>$ 0.05). Possible responses were: $1=$ never, 2 = a few times this semester, $3=$ one or two times a month, $4=$ one or two times a week, and 5 = every session.

d.f. $=164, \mathrm{t}=0.40, p=0.69 ; \mathrm{t}=0.68, p=0.50$; respectively).

Next, we tested for long-term relationships between completion of the two new courses and student content knowledge through analysis of student scores on the BFT. We first confirmed that scores on the BFT were aligned with differing cognitive abilities of students. The scores for senior students, who answered divergent (i.e., higher level) and convergent (i.e., lower level) questions during one-on-one interviews, were highly and positively correlated with their scores on the BFT (d.f. $=1,29 ; r^{2}=0.64$ and $r^{2}=0.53$, respectively; $\left.p<0.001\right)$. We then investigated specific variables that may have contributed to, or at least been correlated with, student BFT scores. Data for five continuous variables (total GPA, GPA in the major, GPA for upper-level biology courses, composite ACT score, and the number of biology credit hours completed) and one categorical variable (whether or not the two new courses were completed) were entered into a multivariate stepwise regression analysis. Only students for which data on all six variables were available were included in the analysis. Of the five continuous variables, only the GPA in the major contributed significantly to the regression model for BFT score (d.f. $=1,131 ; \mathrm{F}=15.11, r^{2}=$ $0.10, p=0.0002)$. We then tested for an effect of completion of the two new courses. The regression model differed significantly between students who had and had not completed the new courses (model d.f. $=2,129 ; \mathrm{F}=3.65$, $p=0.029$ ). There was no significant interaction between GPA in the major and completion of the new courses. To better understand why completion of the new courses was a significant factor in the regression analysis, we com- pared mean scores on the BFT for students who did ( $\mathrm{n}=$ $71)$ and did not $(n=56)$ complete the new courses. Students who completed the new courses had significantly higher percentile scores (all $t$ tests, $p<0.05$ ) for two of the four subcategories of the test, and total scores that averaged 11 percentile points higher compared with seniors lacking the two new courses (Figure 3).

\section{DISCUSSION}

Our results were consistent with the claim that short-term exposure to an intense learner-centered inquiry-based classroom experience, early in the major, enhances student understanding of biology as a process of inquiry and long-term learning of biological concepts. Differences in learning between students in the original and revised curricula were not apparent early in the major but were apparent among senior students. These results were consistent with teaching that focuses on conceptual change rather than information retention. Students were provided with opportunities to understand and experience biological phenomena in new ways through use of learner-centered inquiry-based pedagogy. As a result, students were encouraged to challenge and rethink their prior conceptions about science. Such thinking is dynamic and supports subsequent learning (Donovan and Bransford, 2005). We suggest that the learning experiences encountered by students served as a framework to "reorient" their thinking as they went through their degree program, potentially contributing to increased learning. Because our study was correlative in nature, however, we cannot conclude that completion of the new courses themselves caused improved learning. We can conclude, however, that positive relationships existed between 
A

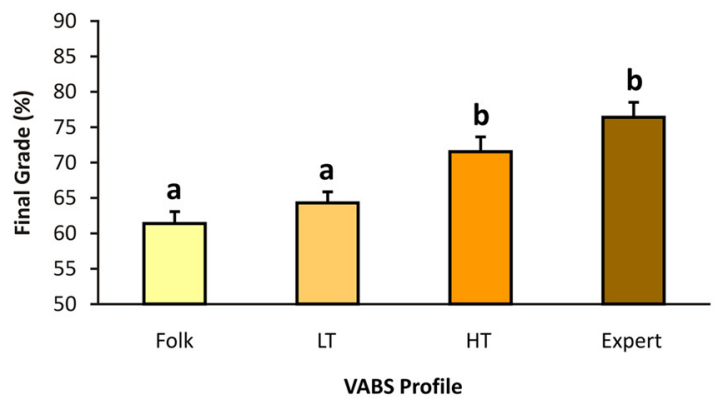

C

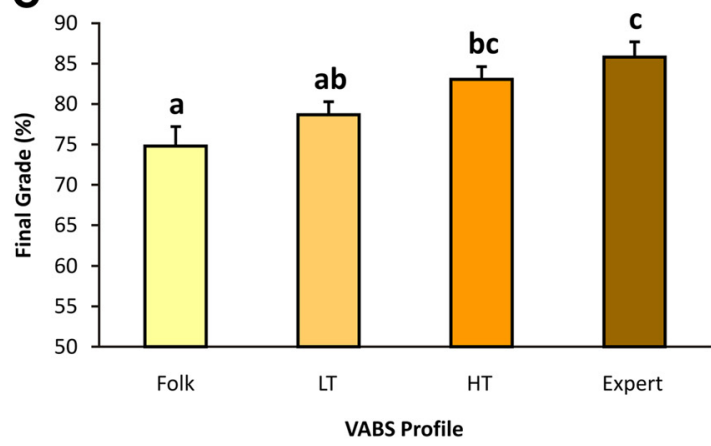

E

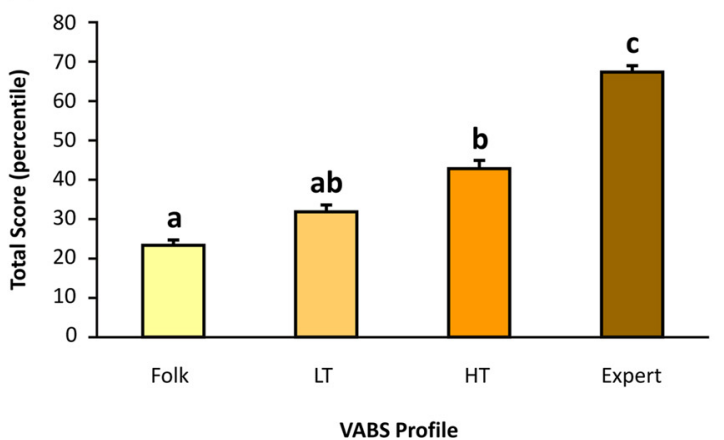

VABS Profile
B

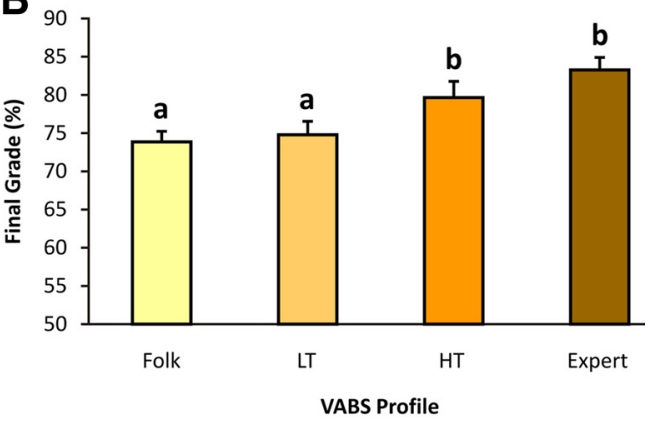

D

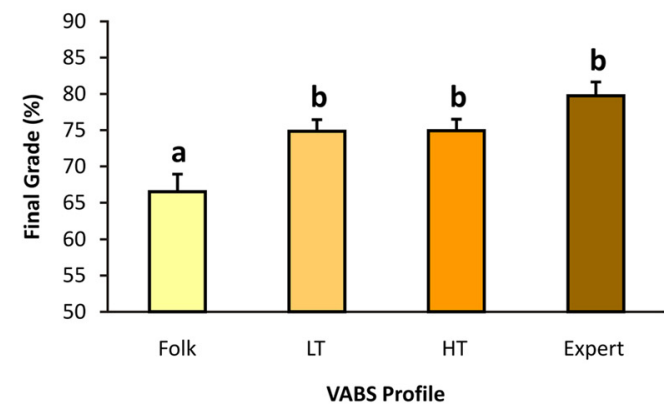

Figure 1. Final grades $(\bar{X} \pm 1$ SE) of first- and second-year students at the end of the semester in TCBL $(n=148$; A), BIA ( $n=151$; B), Zoology ( $\mathrm{n}=155 ; \mathrm{C})$, upper-level students in 300-level courses (Ecology, Genetics, and Comparative Vertebrate Anatomy, $\mathrm{n}=79 ; \mathrm{D})$, and the total percentile scores on the BFT for graduating seniors $(n=129 ;$ E) according to their VABS profile (LT, low transitional; HT, high transitional). Means within a panel that share a letter above the histogram bars are not significantly different from each other (ANOVA, $p>0.05)$.

completion of the courses and our measures of student performance two to four years later. We posit that immersion of biology students in learner-centered inquiry-based classes early in their major was, indeed, associated with long-term improvement in learning based on improved scores on a nationally validated standardized test. Furthermore, revision of just one semester of an eight-semester major may contribute significantly toward improving student learning in science.

Based on student reports (Tables 3 and 4), the pedagogy that was used in the new courses was consistent with the objective of implementing a new curriculum that enhanced student learning of key concepts and understanding of the process of science (NRC, 2002). The extent to which active learning and learner-centered pedagogy was implemented in the two new courses differed, however. The teaching and format of BIA was much less similar to that of the traditional introductory courses than was the teaching of TCBL, as well as the teaching of the 200-level core courses. The greater level of learner-centered pedagogy used in BIA stemmed from its format of small class sections that focused on hands-on research, simulations, student presentations, and frequent assessments that included extended response questions. In contrast, student learning in TCBL was based on a large lecture format interspersed with small group discussions and multiple-choice assessments. We could not analyze for effects of BIA and TCBL on student learning independent of each other because most students took the two courses simultaneously. We discuss here the contributions 


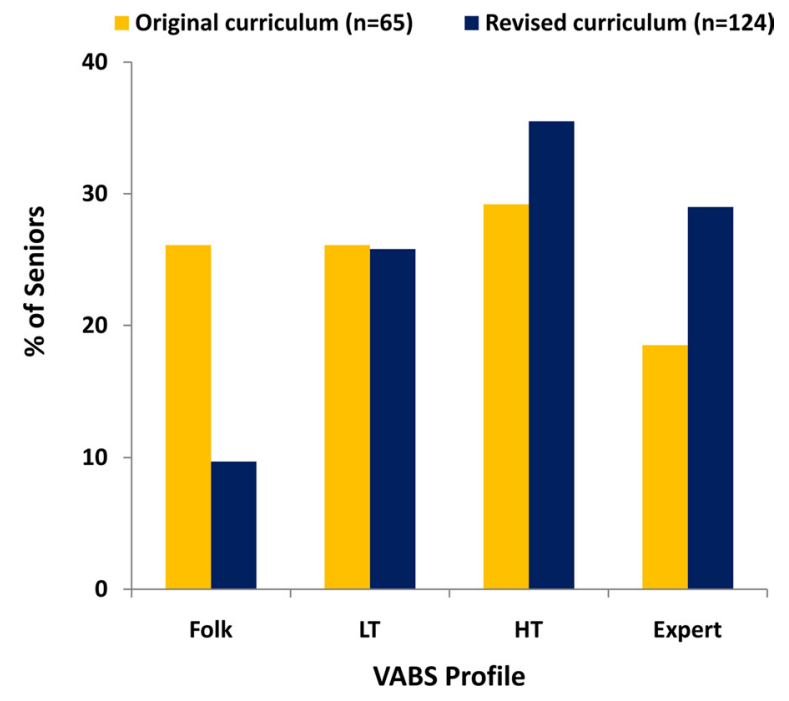

Figure 2. Frequency distributions of VABS profiles of seniors who had or had not taken the two new courses (LT, low transitional; HT, high transitional).

of each potential impact of the revised curriculum to student learning.

\section{Views about Biology}

Relationships between measures of learning and completion of the new courses were not immediately apparent. For example, gains on the VABS did not occur immediately upon completion of a first-semester course (i.e., BIA). Delayed impacts of inquiry-based experiences are not surprising, however, because understanding the process of science probably requires study of its use in many different contexts and longerterm study and practice of its methods. The absence of shortterm improvements may also be a consequence of the strength with which students maintain prior conceptions of what sci- ence is and its relevancy (or lack thereof) to them and the world (Garvin-Doxas and Klymkowsky, 2008; Klymkowsky and Garvin-Doxas, 2008). Differences in profile distributions among seniors (Figure 2) showed that early exposure to courses that emphasized the process of science was positively correlated with, and potentially facilitated, development of the type of thinking and skills that characterize professional scientists.

Students with a more realistic understanding of what science is and how it is learned typically have greater learning gains in high school and undergraduate courses. Halloun and Hestenes (1996) and others (e.g., Baker and Piburn, 1991; Reif and Larkin, 1991; Songer and Linn, 1991) argued that student understanding of the scientific process may be a major determinant of what they learn in physics and other science courses. Our data supported their contention with final grades in 100-, 200-, and 300-level courses and total scores on the BFT that were significantly higher for students with higher-level VABS profiles compared with those having lower-level profiles (Figure 1). Although our analyses do not determine cause and effect, the results suggested that the more developed students' views were about learning biology and the more sophisticated their understanding of biology as a scientific endeavor, the more students learned in subsequent courses. Similar results were reported for a sample of over 1500 high school physics students (Halloun and Hestenes, 1996). Thus, incorporation of classroom activities that enhance students' understanding of science as a human endeavor at any point in a curriculum may be key to improving student learning of science. If VABS profiles of students could be improved within their first year of study, then we predict that the students would perform at a higher level for the remainder of their science courses.

\section{Student Content Knowledge}

Completion of the new courses was correlated with a marked improvement in student scores on the BFT (Figure 3), suggesting that some aspect(s) associated with implementation of the new courses was related to improved stu-
Figure 3. Differences between mean percentile scores on the BFT for seniors who completed both of the new courses $(\mathrm{n}=71)$ compared with those who did not $\left(\mathrm{n}=56 ; t\right.$ test, $\left.{ }^{*} p<0.05,{ }^{* *} p<0.01\right)$.

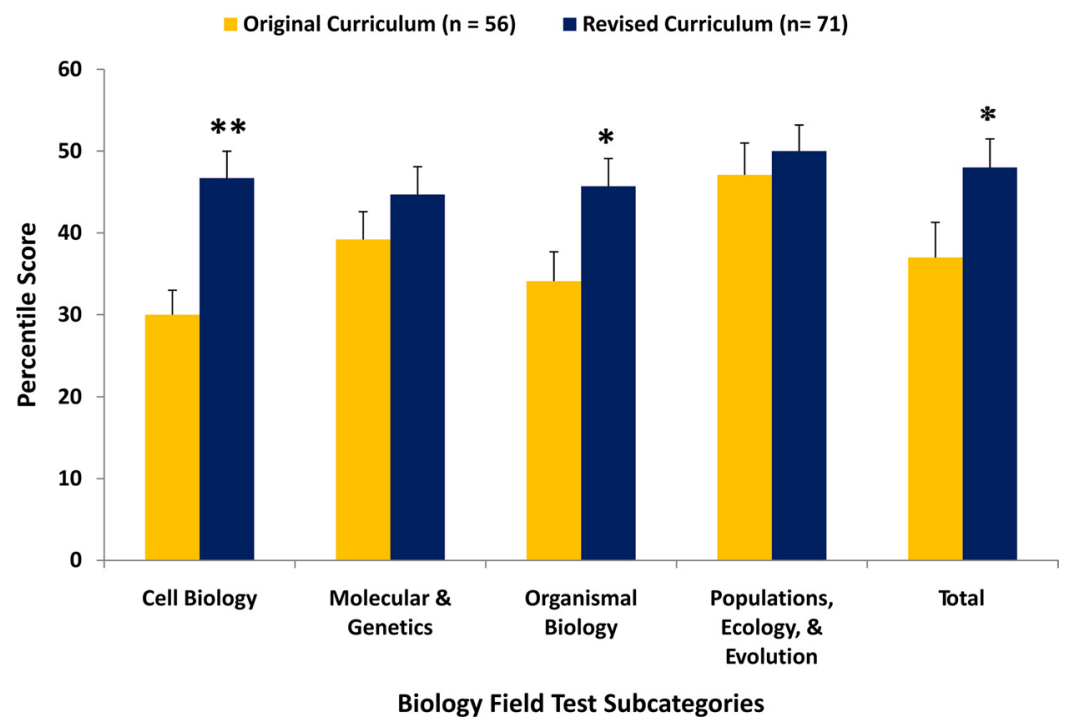

CBE-Life Sciences Education 
dent learning. It is possible that just the addition of the two new courses, regardless of the pedagogy used, was a major factor contributing to the higher scores. If that were the case, then we expected scores to increase primarily in the Cell Biology and Population, Ecology, and Evolution (PEE) subcategories of the BFT because the two new courses had content emphases in those areas. While there was a significant increase in scores on the Cell Biology subsection, there was no significant increase in the PEE subsection (Figure 3). Thus, simply adding a course did not necessarily result in improved BFT scores in that content area. Furthermore, the number of completed biology credit hours was not a significant variable in our multivariate analysis for BFT scores. Accordingly, simply taking more (or fewer) courses was not associated with overall learning of content, at least not as indicated by the BFT.

Conversely, the average score on the Organismal section of the BFT was significantly higher for students who completed the two new courses, even though organismal biology was not a content focus in either new course. A likely explanation for the difference in scores on the Organismal subsection was changes in the teaching of the two organismal courses, Zoology (BIO 221) and Botany (BIO 222), with the curriculum revision. Some differences in teaching of the 100- and 200-level Zoology and Botany courses were apparent based on student reports (Tables 3 and 4). Faculty may have intentionally or unintentionally refocused their teaching of Zoology and Botany content in the 200-level courses after implementation of the new courses, resulting in improved scores on the Organismal subcategory. If that were the case, then we expected the scores on the Organismal subcategory to be higher for students who completed Zoology and Botany after the new curriculum was in place (i.e., 200-level courses) compared with students who took the original 100-level Zoology and Botany. To investigate this possibility, we compiled data for seniors who had not taken the new courses, but who had taken either the 100- (original curriculum) or 200-level (revised curriculum) Zoology and Botany courses. The latter group consisted of seniors who received substitute credit for the new courses by scoring a 5 on the AP Biology Exam in high school, transfer students who had already completed a one-year introductory biology course sequence before transferring from another institution, and seniors who put off taking BIA and TCBL until their last semester of the major. There was no significant difference in mean scores on the Organismal subcategory between the students who took the original 100-level Zoology and Botany courses and those who took the 200-level versions (all $t$ tests, $p>0.05$; 200-level Zoology and Botany, $\mathrm{n}=60$; 100-level Zoology and Botany, $\mathrm{n}=55$ ). Thus, we have no evidence that improved scores on the Organismal section of the BFT after the curriculum revision was a consequence of changes that may have occurred in the teaching of Zoology and Botany, independent of the two new courses.

We conjecture that two factors were of primary importance to improved student learning. First, understanding what science is (and is not) and how it is conducted provides students with a framework upon which to build and assimilate subsequent scientific knowledge (Fosnot, 1996; Donovan and Bransford, 2005; Etkina et al., 2005). Second, intensive practice of higher-level thinking, problem solving, oral and written communication, and collaborative inquirybased activities provides students with skills and group interactions that facilitate learning in any science class (Smith et al., 2005). Our results are consistent with those of many prior studies (e.g., Hake, 1998; Michael, 2006); indicating that teaching practices that emphasize conceptual understanding and practice of science contribute significantly more to long-term learning of science than a traditional teacher-centered lecture approach to introductory courses.

As with any research conducted in an authentic educational context, we cannot state that there were no differences between our two study populations that may have affected our results. Although we detected no significant differences in variables such as hours employed, parents' education level, ACT score, senior GPA, and credit hours completed, other characteristics may have differed. For example, students' level of motivation for academic study, professors' enthusiasm or teaching styles, and the elective biology courses completed by students in the two groups may have influenced the observed outcomes. Also, pedagogy used by faculty who taught the new courses may have extended to other courses that they taught. Three of the six faculty who taught BIA were tenure-track faculty who regularly taught elective upper-level courses. One of the three faculty specifically incorporated inquiry-based pedagogy into an upperlevel course (personal communication). The professor who taught TCBL also taught our upper-level cell biology course. As a result of these confounding variables, we cannot attribute the improvements in learning solely to the two new courses. We must, therefore, be prudent in interpreting the results and identifying factors that explain them.

\section{CONCLUSION}

Current understanding of the impacts of curriculum reform projects in STEM disciplines is limited largely to short-term impacts; specifically, those occurring within the time frame during which one or two courses are taught. The results from short-term assessments have established that learnercentered inquiry-based approaches to teaching enhance student learning (e.g., Freeman et al., 2007). Our longitudinal data indicated that the benefits of learner-centered teaching may extend far beyond the class(es) in which such teaching occurs.

Our results showed that exposure to two courses that use scientific teaching to enable students to inquire and think critically about science was associated with sustained improvements, at least when the exposure occurred early in the curriculum. Simply stated, we propose that students learned how to learn science early in their curriculum. In addition, we propose that in subsequent lecture-based courses, students were able to draw upon their ability to think critically about science and during that process learn concepts better. Accordingly, transformation of introductory biology curricula in biology departments through learner-centered inquiry-based teaching may have the potential to profoundly impact learning by all students and even become a tipping point for departmental change. Without question, studies that determine causal effects of learner-centered inquirybased learning approaches, rather than correlative relation- 
ships, are needed to test our proposed explanation. In addition, we need studies that investigate relationships between the timing of learner-centered courses (i.e., early or later in the major) and subsequent student performance.

\section{ACKNOWLEDGMENTS}

We thank D. Canning, C. Fuller, W. Spencer, S. Wright, H. Whiteman, and the many other faculty and students who assisted with the project and data collection. We thank Dr. I. Halloun for providing us with the materials needed to use the Views About Biology Survey B12. K. Fairbanks' assistance with statistical analyses was greatly valued. We also appreciate T. Timmon's support throughout the project and financial contributions from J. Mateja and N. Weber. The research was funded by a National Science Foundation grant (NSF CCLI A\&I, 9980913) to the senior author.

\section{REFERENCES}

Baker, D. R., and Piburn, M. (1991). Process skills acquisition, cognitive growth, and attitude change in ninth grade students in a scientific literacy course. J. Res. Sci. Teach. 28, 423-436.

Bloom, B. S. (1956). Taxonomy of Educational Objectives, the Classification of Educational Goals, Handbook I: Cognitive Domain, New York: David Kay Co.

Bransford J. D., Brown A. L., and Cocking R. R. (eds.) (1999). How People Learn: Brain, Mind, Experience, and School. Washington DC: National Academy Press.

DeHaan, R. L. (2005). The impending revolution in undergraduate science education. J. Sci. Educ. Tech. 14, 253-269.

Donovan, M. S., and Bransford, J. D. (eds.) (2005). How Students Learn: Science in the Classroom, Washington DC: National Academies Press.

Ebert-May, D., Batzli, J., and Lim, H. (2003). Disciplinary research strategies for assessment of learning. Bioscience 53, 1221-1228.

Ebert-May D., and Hodder, J. (2008). Pathways to Scientific Teaching, Sunderland, MA: Sinauer Associates.

Etkina, E., Mestre, J. P., and O'Donnell A. (2005). The impact of the cognitive revolution on science learning and teaching. In: The Impact of the Cognitive Revolution on Educational Psychology, Charlotte, NC: Information Age Publishing.

Fosnot C. E. (1996). Constructivism: Theory, Perspectives, and Practice, New York: Teachers College Press.

Freeman, S., O'Conner, E., Parks, J. W., Cunningham, M., Hurley, D., Haak, D., Dirks, C., and Wenderoth, M. P. (2007). Prescribed active learning increases performance in introductory biology. CBE Life Sci. Educ. 6, 132-139.

Garvin-Doxas, K., and Klymkowsky, M. W. (2008). Understanding randomness and its impact on student learning: learned from building the biology concept inventory (BCI). CBE Life Sci. Educ. 7, 227-233.
Hake, R. (1998). Interactive-engagement versus traditional methods: a six-thousand-student survey of mechanics test data for introductory physics courses. Am. J. Phys. 66, 64-74.

Halloun, I. (1996). Views about science and physics achievement: The VASS story. Proceedings of the International Conference on Undergraduate Physics Education, College Park, MD: American Institute of Physics Press.

Halloun, I., and Hestenes, D. (1996). Interpreting VASS dimensions and profiles. Sci. Educ. 7, 553-577.

Handelsman, J., et al. (2004). Scientific teaching. Science 304, 521522

Henderson, C., and Dancy, M. H. (2007). Barriers to the use of research-based instructional strategies: the influence of both individual and situational characteristics. Phys. Rev. ST Physics Ed. Res. 3, 020102 .

Klymkowsky, M. W., and Garvin-Doxas, K. (2008). Recognizing student misconceptions through Ed's Tools and the Biology Concept Inventory. PLoS Biol. 6:e3.

Knight, J. K., and Wood, W. B. (2005). Teaching more by lecturing less. Cell Biol. Educ. 4, 298-310

Michael, J. (2006). Where's the evidence that active learning works? Advan. Physiol. Educ. 30, 159-167.

National Research Council (NRC) (2002). Learning and Understanding: Improving Advanced Study of Mathematics and Science in U.S High Schools, Washington DC: National Academy Press.

NRC (2003). Evaluating and Improving Undergraduate Teaching in Science, Technology, Engineering, and Mathematics, Washington DC: National Academy Press.

Phillips, A. R., Robertson, A. L., Batzli, J., Harris, M., and Miller, S. (2008). Aligning goals, assessment, and activities: an approach to teaching PCR and gel electrophoresis. CBE Life Sci. Educ. 7, 96-106.

Prince, M. (2004). Does active learning work? A review of the research. J. Eng. Educ. 93, 223-231.

Reif, F., and Larkin, J. H. (1991). Cognition in scientific and everyday domains: comparison and learning implications. J. Res. Sci. Teach. 23, 177-187.

SAS Institute (2008). User's guide. Version 9.2. Cary, NC.

Seymour, E. (2006). Undergraduate science, math, and engineering education: what's working? Testimony offered to the Research Subcommittee of the Committee on Science of the US House of Representatives hearing. Washington, DC.

Smith, K. A., Sheppard, S. D., Johnson, D. W., and Johnson, R. T. (2005). Pedagogies of engagement: classroom-based practices. J. Eng. Educ. 1, 87-101.

Songer, N. B., and Linn, M. C. (1991). How do students' views of science influence knowledge integration? J. Res. Sci. Teach. 28, 761-784.

Udovic, M. D., Dickman, A., Postlethwait, J., and Wetherwax, P. (2002). Workshop biology: demonstrating the effectiveness of active learning in an introductory biology course. Bioscience 52, 272-281.

Wood, B. W., and Gentile, J. M. (2003). Teaching in a research context. Science 302, 1510. 